\title{
Thucydides' Trap in the Business World: Corporate Strategy for a new Geopolitical Reality
}

\author{
Stefan Legge Tomas Casas
}

March 29, 2020

\begin{abstract}
$\underline{\text { Abstract }}$
When a rising power threatens the position of an incumbent power, historically the result has been war. This conjecture derived from the analysis of the Peloponnesian War by Greek historian Thucydides (460-400 BC) has borne out up to modern times. Statistically, three out of four such situations ended in war according to Graham Allison who has characterized observations of this type of conflict and their underlying dynamics as Thucydides' Trap. This concept is of primary relevance today for policymakers worldwide, as China and the United States intensify their rivalry. In the present paper, we extend Thucydides' Trap to the world of business. First, we explain that the underlying dynamics of the trap are at play in the business world as well. Rising companies constantly threaten the position of incumbent market leaders. Unlike politicians, however, managers have several strategic options to avoid falling into Thucydides' Trap. Nevertheless, this changes in the new geopolitical landscape which is characterized by the Sino-American rivalry as well as intensified nationalism and deglobalization. We point out how the managerial strategy space is narrowed by a new geopolitical reality: aggressive corporate responses are more likely in world dominated by two superpowers caught in Thucydides' Trap. We discuss the implications of this new contextual reality for the strategy of multinational firms.
\end{abstract}

Corresponding author: Stefan Legge, University of St.Gallen, SIAW Institute, Bodanstrasse 8, CH-9000 St.Gallen, Switzerland.

E-mail: stefan.legge@unisg.ch

For numerous helpful comments, we are grateful to Winfried Ruigrok as well as Simon Evenett. 


\section{Introduction}

The United States and China are likely to be already entangled in what Graham Allison described as Thucydides' Trap. The term characterizes the historical observation that conflict is a likely outcome when a rising nation threatens the dominance of the incumbent world power. At the core, this is the result of both rational interest calculation as well as human sentiments like fear, pride, and claims of validity. The combination leads to a series of biases in top decision-makers including tunnel thinking, limited information processing, and bounded rationality. This can happen even if both parties are fully aware of the situation: "Despite the mutual awareness of the Thucydides Trap - and the recognition that history is not deterministic - China and the US seem to be falling into it anyway", wrote Nouriel Roubini (Project Syndicate, May 20, 2019). The latest developments with regards to the COVID-19 pandemic (including the dismissal of journalists) only support this assessment.

To the extent that business leaders can suffer from similar affective and cognitive biases, we should expect the dynamics of Thucydides' Trap at play in the corporate world as well. However, the relative rarity of corporate rivalry turning into outright business conflict raises the question about how managers have avoided falling into the trap when emerging and incumbent firms face each other.

Our article has two main conceptual parts. First, following the definition of how we understand the dynamics behind Thucydides Trap, we apply the concept to the business world and articulate the wider choice set available to managers compared to states leaders who must deal with foreign rivals. Then in the second part, we examine how the present geopolitical reality of rising political tensions impacts decision-making in the executive suite. We are the first to bring the idea of Thucydides' Trap to business strategy, and to transition the concept from the macro level to the firm level.

The first part proposes a framework of the Thucydides Trap for the corporate world. Like in the original conceptualization of the trap, the unit of analysis are decision-makers (not abstract nations) who engage in flawed decision-making and miscalculate. Like politicians, managers are liable to mistakes when their circumstances resemble those of politicians considering war. But there are critical differences in the dynamics between incumbent and raising businesses as we point out. We also summarize the strategies that corporate leaders implement to avoid costly and uncertain outright conflict, the business equivalent of Thucydides' Trap. This necessitates a discussion of how these strategies are affected when an actual geopolitical trap shapes the business landscape. The current US-China rivalry brings this discussion to life: The rising Middle Kingdom has its own institutions that are markedly distinct from Western equivalents. Matters like new rivals being state-supported and hailing from ecosystems that operate under very different sets of rules and values from those of the U.S. and its allies are both relevant and unprecedented. 
In the second part of the article, we analyze how managers' choice set is narrowed due to the SinoAmerican geopolitical competition. Business rivalry is paralleled and exacerbated by the superpower rivalry, but it transcends the U.S. and China as every multinational company is touched and the idea of national champions spreads in Europe and other parts of the world. This new geopolitical reality is characterized by reduced cross-country political cooperation, having first-order implications for business leaders. As we point out, corporate strategies to deal with rivals in this context tilt toward more aggressive options. Counterintuitively, increased power competition among nations can lead to advantages for individual business and to less competitive markets. When business leaders of incumbent American firms face a rising competitor from China, several of the key options to successfully respond are no longer available. We argue that this is a factor for the increased acceptance of - if not outright support for - anti-Chinese policies implemented ever more aggressively by both the United States and European countries.

We conclude by bringing the two arguments together and suggesting that managers can benefit substantially from adjusting their corporate strategy. Our article provides an overview of corporate approaches to rising competition and how in this day and age strategies will adjust when the business environment changes due to geopolitical dynamics. To illustrate strategic opportunity, we enrich the article with numerous business cases and examples. For this, we draw from our own research, and refer to numerous published studies. The key goal of our article is to provide a framework of reference when top executives adjust strategy in the face of the complexity brought about by a shifting geopolitical landscape.

\section{Thucydides' Trap in Business}

Political scientist Graham Allison developed the idea of Thucydides' Trap, arguing that when a rising nation threatens the dominance of an incumbent superpower, more often than not the result is war. The fatal dynamics was first described by Greek historian Thucydides in his account of the Peloponnesian War: "It was the rise of Athens and the fear that this inspired in Sparta that made war inevitable". Political decision-makers are trapped, and not just by unusual, unexpected events. Even ordinary flashpoints can easily escalate to the point of large-scale conflict in a system where there is anarchy. That is, were no higher instance of appeal exists. Currently, the deterministic idea of Thucydides' Trap has transcendent to the public domain and receives significant attention used to elucidate the present and future of the Sino-American relationship. Policymakers and commentators discuss whether the world's two largest economies are on a structuralist path toward severe conflict. This idea is supported 
by events like the trade war starting in 2018 or the rising technological rivalry exemplified by the recent cases of ZTE and Huawei.

In the world of business, the situation of a rising party threatening the dominant position of another player sounds all too familiar. Market-dominating firms are frequently challenged by rising competitors through the use of innovative and disruptive technology or business models. This gives rise to the question whether the dynamics of the Thucydides' Trap are at play in business as well. Do firms end up in a conflict - such as a price war - or are the worlds of geopolitics and business so distinct that firm rivalry is resolved in less destructive ways?

Modern corporations are powerful organizations. Recent work by Zingales (2017) documents that 69 of the largest 100 corporate and government entities ranked by revenues were corporations. Apple's profit in 2018 of about $\$ 60$ billion exceeded the German military budget. However, it is not only financial might. Also in regard to other features, the largest companies wield significant political power and are more than a simple "nexus of contracts" (Jensen and Meckling, 1976). In dealing with rival companies, business leaders have a full arsenal of strategic options which often resemble how states respond to military challenges: alliance-building, financial attacks, cutting off rivals from vital resources, price wars, or even espionage. Only lacking the power to wage war or to detain people, how do businesses protect their privileged positions when dealing with emerging rivals threatening to disrupt - without the risk of falling into a costly and uncertain business war?

There are key parallels but also differences between the world of politics and business. Among the similarities, decision-making occurs at the individual level. Business leaders have objectives and motivations similar to politicians. Think of the CEO's pride and interest in wanting the company to remain the market leader. However, unlike competing nation states, competing businesses are subject to a legal and regulatory framework. National laws are much more binding for top companies than international laws or the UN charter are for powerful nations. The license to operate can be withdrawn from law-breaking firms, the right to exist cannot be taken from important nation states. This significantly limits the spectrum of strategies, especially at the aggressive end of the range, a company can exploit in dealing with a rising competitor.

How would a 'war' between firms look like in the rules-based framework of business? Price wars provide a prominent illustration. While Stadie et al. (2019) find that more than half of all companies worldwide believe to be involved in a price war, this is mostly a reflection of the competitive nature of markets. Furthermore, aggressive price reductions force losses and eventually firms must turn their increased market shares into profits or respond to shareholders. Other forms of aggressive firm behavior also fall short due to costs or legal considerations. These include hostile takeovers, exclusive contracts with vital suppliers to cut off rivals from necessary inputs, hiring talents from rival firms, 
bogus lawsuits or even theft of intellectual property, even if the latter has involved illegal activities resembling the intelligence work of states.

What then are the strategies of choice to respond to the threat from new competitors? Suppose a rising company uses new technology or provides a different product or service, disrupting the supply or demand side of the incumbent firm's market. If successful, the rising firm experiences a continued increase in its market share as illustrated in Figure 1.

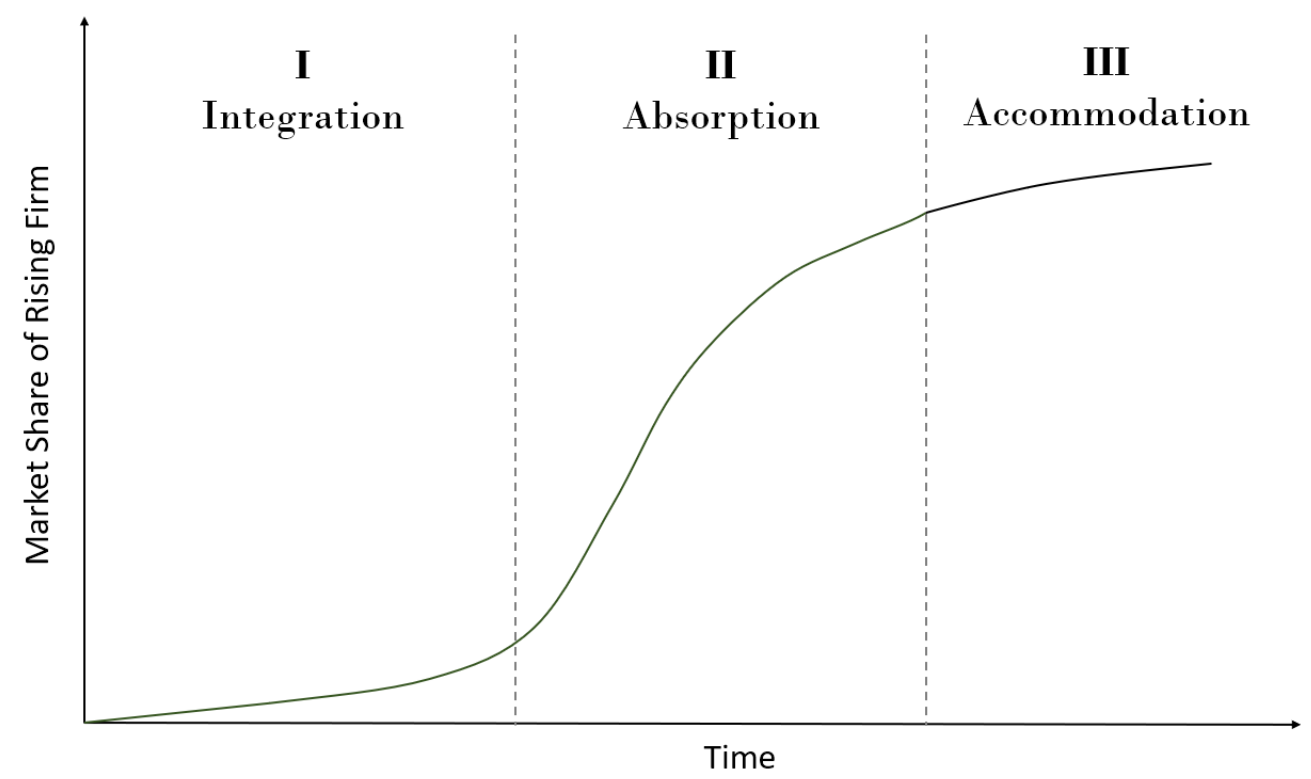

Figure 1: Thucydides-in-Business Framework: Staged strategic responses to a rising competitor

For a significant time after inception, marked as Stage I in Figure 1, the rising firm will operate largely under the radar. Its share of the relevant market might be so small that the market-dominating company does not think of it as a future competitor. This early stage is, however, crucial for the incumbent firm to spot new rivals. But as history tells, future rivals are often overlooked. Note in this regard the successful low-cost or focus strategies by Huawei, Amazon or Toyota during their initial expansion. Clayton Christensen's 1997 book The Innovator's Dilemma as well as its 2003 successor The Innovator's Solution, point out that incumbent firms can easily overlook potential competitors if they "do not look like us". Classic examples in this regard are Kodak's miss of photo sharing despite its purchase of Ofoto in 2001 or Blockbuster's decision not to purchase Netflix for $\$ 50$ million in the year 2000 . Aware of the potential for such mistakes, many incumbents today invest aggressively in R\&D to develop innovation in-house or they support early-stage firms with their corporate VC funds. The latter response is one of integration of potential future competitors. This is not unlike geopolitics, where American 
policymakers up to the Obama administration sought to integrate China into the U.S.-designed global system of rules and institutions.

If the new firm illustrated in Figure 1 increases its market share and advances to Stage II, it starts to pose a more serious threat to the incumbent firm, and the latter might feel the urge to respond more aggressively. This is when Thucydides' trap snaps in geopolitics. But does the rise of a disrupting company and the strategic concern that this inspires at the incumbent lead to similar dynamics with aggressive attacks aiming at the destruction of the challenger?

The case of WhatsApp in its early years provides insight. Early on, soon after its release in early 2009, incumbent Facebook noticed the threat from WhatsApp. It probably could have bought WhatsApp while the rising firm was still small, and the acquisition price would have been modest. Instead Facebook launched its own messenger standalone iOS and Android apps in August 2011. Despite the new competition, WhatsApp's superior user experience saw its market share increase rapidly. Facebook's initial strategy had failed, and the company moved to an absorption strategy, ultimately deciding to purchase WhatsApp for $\$ 19.3$ billion in February of 2014. While being an expensive decision, it prevented WhatsApp from entering Stage III of Figure 1 and being a permanent competitor to Facebook with all the attendant costs of an ongoing rivalry.

Making it to Stage III is the strategic objective of emerging firms. The aggressive behavior of online business provides an illustrative example. Targeting the same customers as brick-and-mortar incumbents, their ultra-low pricing was supported by incommensurable VC-funded price war chests. Another example is given by Snap, the rising start-up known for its Snapchat image messaging product. It refused Facebook's entreaties, as well as Google's $\$ 30$ billion offer in 2016, and instead decided to aim at dominant status via the IPO route. While Snap went public at a high valuation at \$24 billion, Facebook pre-emptively launched an effective product war with Instagram Stories and WhatsApp Status. Snap got cornered and was never able to gain the expected traction. Its daily active users languish in tandem with its stock price (around \$18 billion in March 2020) which is now below IPO level.

As these examples illustrate, businesses have a range of options to deal with rising competitors. Most notably, established Silicon Valley firms purchased a plethora of small but promising start-ups early on in Stage I to avoid both competition and hefty price tags. On the other side of the game, Silicon Valley VCs provide hordes of cash and other resources to potentially disruptive new firms.

What happens if incumbents miss a rising firm which then becomes a strong contender in Stage III? We argue that the preferred response in Stage III is one of accommodation, an oligopolistic entente of sorts to avoid costly attrition. This is not always the case, and the classic Honda vs. Yamaha motorcycle war of the early 1980's is an extreme example of Thucydides Trap in business (Abegleen and 
Stalk, 1985). Yamaha tried to take advantage of Honda's investments in U.S. car factories and decided on an all-out attack by increasing capacity. President Koike noted in 1982: "In one year, we will be the domestic lead. And in two years, we will be number one in the world." Honda's president Kawashima was equally belligerent: "As long as I am president of this company, we will surrender our number one spot (in motorcycles) to no one. [...] Yamaha has not only stepped on the tail of a tiger, it has ground it into the earth.” And if the message was not clear, he exclaimed: “ヤマハをつぶす!“(We will crush, squash, and slaughter Yamaha!). How does war between two large companies look like? Key elements were substantial price cuts, increases in promotions funds, dealers making $10 \%$ more with Honda, and 81 new motorcycle models. The result? Yamaha's president conceded defeat on June 8, 1983: "We plunged like a diving jet. My ignorance is to blame." The newly appointed Yamaha President Eguchi articulated what defeat entails: "Since Yamaha is considered responsible for the present market situation, I would first like to study our position and develop a more cooperative stance toward other companies [...] Of course, there will still be competition [...] but I intend it to be based on mutual recognition of relative positions."

Outright conflict did not pay off for Yamaha because of Honda's response. The set of options that incumbent firms possess to respond to threats to their dominant position in Stage III is varied. Some are akin to what states can do to fight off rival superpowers. However, in the business world the options are more nuanced and numerous as we discuss in the next section.

\section{How Executives Compete}

So far, we have described that business leaders, unlike their political peers, have wider strategic framework to engage in Thucydides' Trap situations. In what follows we point to specific strategic responses of firms to deal with rival companies. We will see how these available options tilt toward more aggressive approaches in the new geopolitical order characterized by China and the United States caught in Thucydides' Trap.

Businesses constantly face competitive challenges, and these are typically addressed with strategic responses such as cost leadership, out-innovation or brand-building. Should traditional strategies be insufficient to address the challenge posed by a strong rival, orderly cooperative responses are a first possibility. These range from the purchase of a rival to partnership with a former competitor. To illustrate this point, consider the dispute between Qualcomm and Apple in which the former knew it was Apple's only viable supplier of $5 \mathrm{G}$ chips. Not surprisingly then, Apple ended the battle with a legal 
claim exceeding US\$ 1 billion and settled in early 2019. In Table 1, we list strategic responses and sort them from friendly (on top) to less friendly. For each strategic response, we provide both a description as well as several cases and examples.

\begin{tabular}{|c|c|c|}
\hline Strategic Response & Description & Cases / Examples \\
\hline Partnership & Joint venture, coopetition & $\begin{array}{c}\text { GM and Toyota at NUUMI; Samsung and Sony } \\
\text { for flat-screen LCD (Gnyawali et al., 2011); } \\
\text { Microsoft with Office on Apple products }\end{array}$ \\
\hline Co-Existence & $\begin{array}{c}\text { Allow the rival to keep face as } \\
\text { minor player that poses no } \\
\text { threat (live and let live) }\end{array}$ & Honda and Yamaha post-dispute \\
\hline Collaboration & $\begin{array}{c}\text { Friendly oligopoly } \\
\text { short of cartel }\end{array}$ & $\begin{array}{c}\text { German premium car manufacturers; } \\
\text { Pepsi and Coca Cola; DeBeers and Alrosa }\end{array}$ \\
\hline Dependencies & $\begin{array}{c}\text { Enforce collaboration through } \\
\text { dependencies incl. patents }\end{array}$ & $\begin{array}{c}\text { Chinese electronics dependence on American } \\
\text { semiconductors (evidenced by ZTEs 2018 } \\
\text { embargo) and China's attempt to break such } \\
\text { dependence (China 2025 initiative); } \\
\text { patent trolls (GDPR) }\end{array}$ \\
\hline Purchase Rival & $\begin{array}{c}\text { Combine the two competing } \\
\text { companies in a friendly } \\
\text { manner }\end{array}$ & $\begin{array}{c}\text { Silicon Valley IT firms: e.g. Facebook and } \\
\text { WhatsApp; Microsoft and GitHub }\end{array}$ \\
\hline Spatial Division & $\begin{array}{c}\text { Go separate markets. Includes } \\
\text { splitting the world (on basis of } \\
\text { home market advantages, incl. } \\
\text { customer preferences) }\end{array}$ & $\begin{array}{c}\text { Amazon and Alibaba; Apple not competing } \\
\text { Xiaomi on low-budget smartphones }\end{array}$ \\
\hline Imitation & Develop similar products, \\
learn from rival & $\begin{array}{c}\text { Apple TV+ against Netflix; iTV and BBC launch- } \\
\text { ing a new streaming service, Apple Music } \\
\text { emulating Spotify's model; Chinese manufac- } \\
\text { turers learning from Western firms }\end{array}$ \\
\hline
\end{tabular}

Table 1: Cooperative Responses

If neither basic strategies nor orderly cooperative engagement responses work, business leaders might increase the heat and apply one of several aggressive engagement strategies. Interestingly, some of these include cooperation with the state. For this, we expect to see numerous new examples in the ongoing Sino-American geopolitical rivalry but also in Europe when responding to perceived threats from China. In Table 2, we describe the aggressive strategic responses. Again, the sorting is from less aggressive (top) to more aggressive (at the bottom). 


\begin{tabular}{|c|c|c|}
\hline Strategic Response & Description & Cases / Examples \\
\hline Hostile Takeover & $\begin{array}{l}\text { Purchase competitor despite } \\
\text { lacking its board's support }\end{array}$ & Broadcom's $\$ 130$ billion bid for Qualcomm \\
\hline Regulatory Moat & $\begin{array}{l}\text { Tilt regulation against } \\
\text { rival firms }\end{array}$ & Foreign rival: Huawei and ZTE \\
\hline Copy Ideas & $\begin{array}{l}\text { Various forms of IP theft } \\
\text { (which is getting easier if } \\
\text { countries do not cooperate } \\
\text { legally, or are 'decoupled' } \\
\text { politically) }\end{array}$ & $\begin{array}{l}\text { Chinese companies copying IP (USITC frequently } \\
\text { reports tens of billions of losses for US IP-inten- } \\
\text { sive firms) - including forced transfer of which } \\
\text { 1/5 of European firms felt affected according to } \\
\text { the European Chamber of Commerce }\end{array}$ \\
\hline Price War & $\begin{array}{l}\text { Extreme cost leadership, } \\
\text { often subsidized by other } \\
\text { businesses or state support }\end{array}$ & $\begin{array}{c}\text { Global steel industry, see WTO anti-dumping } \\
\text { cases, Global Trade Alert }\end{array}$ \\
\hline State Alliance & $\begin{array}{l}\text { Partnership with the state: } \\
\text { receive subsidies, politicize } \\
\text { statements and actions of } \\
\text { rival firm }\end{array}$ & $\begin{array}{l}\text { Boeing and Airbus from military procurement to } \\
\text { commercial aircrafts }\end{array}$ \\
\hline Cut off Resources & $\begin{array}{l}\text { Prevent rival to access neces- } \\
\text { sary inputs, including hostile } \\
\text { hiring }\end{array}$ & $\begin{array}{l}\text { China: EV battery materials and rare earths; } \\
\text { Plan } 111 \text { and later the Thousand Talents } \\
\text { Program: not too different from IP theft }\end{array}$ \\
\hline
\end{tabular}

Table 2: Aggressive Responses

A question surfaces when reviewing the politicized response list. What is the relation between the cooperative and aggressive engagement responses in the context of the new geopolitical order? In red we have highlighted in Tables 1 and 2 those strategies that seem less likely to be implemented and succeed in a world characterized by geopolitical rivalry. In contrast, we the expect strategic responses shown in green to gain importance in a Thucydides Trap situation. Three examples of specific situations in which a strategic response is conditioned by the geopolitical situation include:

- Anheuser Bush InBev (ABI) achieved a 25\%+ global market through a \$100 billion merger with the 2nd player SABMiller. It would be much less likely for Western to acquire a controlling stake in one of China's top breweries, even as Heineken bought in 2018 a 40\% stake in CRH Beer owner of market leader China Resources Beer.

- Following the 2016 acquisition of German robot-maker Kuka AG by China's Suning Group, a new European regulatory framework (against China) is currently being drafted. Regulatory moats (e.g., on national interest grounds) tilt rules against foreign players (e.g., local content requirements, import bans, trade policy generally, anti-dumping, targeted political actions, limit rivals' access to technology, prevent acquisition, leverage diplomacy to open foreign markets). This could backfire if the foreign firms built up a domestic presence. 
- State capitalism sees coordination between rivals in pursuit of national interest and direct state support of "national champions". "Non-market competition" is not really new as French firms for instance have long been supported by the state as well. And yet of Made in China 2025 and related government-guided funds, such as the National Integrated Circuit Investment Fund, means that China bests all precedents, as Nicholas Lardy argues in "The state Strikes Back".

In short, the increasingly intense Sino-US conflict alters the business arena with first-order strategic choice implications for managers. Thucydides lurks in all areas of international business such as export opportunities, technological cooperation, access to public procurement tenders abroad, or optimal supply chain choices.

One possible counter-intuitive result of the geopolitical rivalry is that the world of business might become less competitive. Fewer foreign competitors because of tariffs and other trade barriers as well as state support can lead to a situation with a stable and small set of incumbent firms. This would not be a scenario welcomed by economists but potentially by the respective shareholders.

\section{The United States and China fall in the Thucydides' Trap: Deal with it}

For incumbent firms to aggressively respond to new rivals, and for emergent disrupters to draw plans to displace established players, is in the natural playbook of competition. However, the operating assumption is that both incumbent and the rising firms play according to similar rules and principles. For instance, a firm can always purchase a rival if it has superior financial means. But what if the rival is backed by a state that does not agree to its firm being sold to a foreigner, or chooses to support the local player financially with nearly unlimited resources? The different ownership structures and limitations to foreign investment applying to many Chinese firms, and increasingly to Western firms, mean that orderly accommodation approaches, especially in Stage III, are more unlikely when geopolitics enters the scene.

Graham Allison's Thucydides' Trap describes the rise of the China state and the perceived threat to the United States. However, one could argue that it is as much the rise of Chinese global competitors which is perceived as a threat. The Trump administration launched a trade war, and European politicians support new protectionist industrial policies as a result. In some sense, we are witnessing both competition between states using economic leverage and between companies utilizing state leverage.

Managers at leading firms are taking notice: It will not only be the Sino-American relationship that is about to change in the coming years but the policies of the countries international firm invest and 
operate as these respond and take sides the geopolitical conflict. Interestingly, rather than China converging with the West, America is becoming more protectionist and more like China, as The Economist put it in May 2019. Here lessons from the 1980s and 1990s are worth remembering. This was the time when George Friedman wrote about The Coming War with Japan and numerous Western companies felt the competitive threat from the Land of the Rising Sun.

How the Detroit Big Three responded to Toyota and other Japanese manufactures in the 1980s is paradigmatic. Arrogance at the US car industry might have forestalled a response consistent with the threat, and after much disruption American car shares declined from over $70 \%$ in the mid-1980's to under $45 \%$ in the early 2000 where it has stabilized since. Most US loses were Japanese gains, whose market shares have steadily increased reaching $40 \%$ in 2017. Could American car manufactures have acquired Toyota or Honda when they were emerging? The troubled Renault-Nissan partnership suggests otherwise. And as we explained before, if competitors do not play in the same political economy, the strategic responses are less accommodating.

How then should Western business leaders respond to the intensifying competition from China? The period of identifying rivals early-on is over. And in any event Western CEO's being handed Chinese gems are seldom able to recognize these for what they might become. In 2003, Huawei tried to sell itself to Motorola at a $\$ 7.5 \mathrm{bn}$ valuation, but Motorola turned down the deal (Sender, 2019). That was when Huawei started to succeed internationally, and it was doing that on its own before it became a national champion. Yahoo too took a stake in Alibaba, but it never used this asset to enter Chinese e-commerce. Today, Western firms might have learned to respect Chinese ones but increased regulatory differences and state interventions make orderly accommodation more difficult.

The current US-China geopolitical dispute could, in theory, be moderated by the United Nations and other multilateral organizations which could also regulate the rules of business that apply between established and the raising firms when these hail from different countries. Such harmonization would limit the dominant country's ability to design policies - which is precisely why the United States was never keen to support a more influential UN and has generally been skeptical of international organizations like WTO, or the International Court of Justice. In a similar vein, market-dominant firms like Microsoft or Amazon would be unlikely to favor strong competition agencies, to regulate global data policies, monopoly or monopsony positions. Hence, the Thucydides rivalry forces business responses of both incumbents and rising firms to be more aggressive towards each other than if there was a level playing field. Not only that, when incumbents and growing firms enlist the support of their states who are already locked in conflict, the business competition can easily become a prolongation of political conflict. The Thucydides' logics applies to businesses with explosive intensity when it makes its appearance in geopolitics. 
Chinese, Russian and European governments realized the importance of data before it became commonly understood that this was the new oil. Countries that did not have any rivalry with the US allowed American firms to capture their data. They quickly dominated the spaces like search, social networks or e-commerce. On the other hand, the state in China protected its emerging firms, not unlikely the industrial policies of MITI after World War II protected Japanese car manufacturers. As a result, there is Alibaba, Tencent and Baidu in China or Yandex, Mir, and mail.ru in Russia.

Corporate leaders are well advised to have a list of what-if questions for the emerging, balkanized world, including:

- What if the supply chain suddenly gets disrupted by political actions?

- What if new barriers to international trade emerge?

- What if access to foreign markets becomes restricted or there are de-investment requests?

- What if access to key technology gets blocked?

- What if the global economy or large parts thereof fall into recession as a result of unpredictable geopolitical events?

Strategies to cope with the what-ifs include a reduction in exposure to conflict (e.g. Silicon Valley rethinking its contracts with the Pentagon, Cisco cutting manufacturing in China, Western companies following a "China +1 strategy" with production sites in Vietnam), re-organization of global supply chains (Apple's manufacturing choices ahead), precautions for a 'splinternet' (a division of the digital world wherein Western and Chinese nodes would not connect to one another), protection of critical IP from theft, or securitization of access to a large talent pool (Silicon Valley depends on foreign workers).

\section{Outlook}

The Thucydides Trap is the result of anarchy, meaning the absence of a higher order to design and enforce rules. This has been the reality in international state-level relations. In the business world there is always a higher order in the form of laws and a justice system. With order, corporations have an incentive to compete fairly with emerging rivals and prefer the implementation of more predictable less aggressive variants in the staged framework of integration, absorption and assimilation. If, however, the rival firms hail from countries that are at odds with each other in the Thucydides sense, the strategic responses are likely to be more aggressive and uncertain.

The constructive ways in which incumbent/emerging firm dynamics are dealt with in business ought to be an inspiration for international politics. The lesson is that the civility and the rules-based order 
produces more favorable outcomes for all parties involved. However, for competitors hailing from states locked in a Thucydides situation a level playing field is less likely. Firms must closely observe politics and gear up for novel challenges developing new capabilities including the development of narratives to enlist state support like Facebook is doing when it claims that Libra is a Western response the People's Bank of China expected launch of the crypto Renminbi.

Western firms, excluding those in industries like automotive or consumer electronics, survived the rise of Japanese rivals in the 1980s. What is different this time different with China? Japan was a geopolitical ally while China is a geopolitical rival. Moreover, after 1989 it became clear that notable exceptions notwithstanding, Japan's innovation, finance and business models were not as competitive as America's. In contrast, the jury is still out whether China's variety of capitalism can produce more innovative firms, and more inclusive business models and ecosystems.

In the coming years CEOs and top executives will test various approaches. One is multiple identities, like Schlumberger the world's largest oilfield services company with four principal executive offices in Paris, Houston, London, and The Hague. But could Apple or Alibaba be both Chinese and American? In the past, the failure of US multinationals in foreign markets was often the result of lacking an understanding of the differences in business environments. Decision-makers failed to channel local information to upper levels. That could be fixes and companies like Philips or Sony did open their boards to foreigners. Could board members from across the geopolitical divide work well together so that a specific firm is not caught in Thucydean cross-fire?

How will managers in America, Europe and China fare as they experiment with responses to master the brave new world? The underlying question will be the degree to which novel approaches will influence core corporate strategy in response to the new geopolitical reality characterized by a prolonged Sino-US conflict. Multinational companies, which have arguably been the biggest financial beneficiaries of globalization, have the most to lose.

Future historians might use a variant of Thucydides' quote to describe the current situation: "It was the rise of Chinese firms and the fear that these inspired in Western business leaders that made war inevitable". The absence of effective opposition from many US business leaders to US President Trump's trade policy might be seen as testimony that the Thucydides Trap in geopolitics has already extended to the business world. 


\section{$\underline{\text { References }}$}

Abegglen, James C. and George Stalk, Jr. (1985). Kaisha: The Japanese Corporation, New York: Basic Books.

Allison, Graham (2017). Destined for War: can America and China escape Thucydides' Trap?, Houghton Mifflin Harcourt.

Bronnenberg, Bart J., Sanjay K. Dhar, and Jean-Pierre H. Dubé (2009). Brand History, Geography, and the Persistence of Brand Shares, Journal of Political Economy, 117(1), 87-115.

Bronnenberg, Bart J., Jean-Pierre H. Dubé, and Matthew Gentzkow (2012). The Evolution of Brand Preferences: Evidence from Consumer Migration, American Economic Review, 102(6), 2472-2508.

Christensen, Clayton M. (1997). The Innovator's Dilemma: When new technologies cause great firms to fail, Harvard Business Review Press.

Christensen, Clayton, and Michael Raynor (2013). The Innovator's Solution: Creating and sustaining successful growth, Harvard Business Review Press.

Gnyawali, Devi R., and Byung-Jin Robert Park (2011). Co-opetition between giants: Collaboration with competitors for technological innovation - Drivers and Consequences of Collaboration between Large Competitors, Research Policy, 40 (5): 650-663.

Lardy, Nicholas R. (2019). The State Strikes Back: The End of Economic Reform in China? PIIE

Porter, Michael E. (1980). Competitive Strategy. Free Press.

Sender, Henny (2019). How Huawei tried to sell itself to Motorola for \$7.5bn, Financial Times, February 27.

Stadie, Ekkehard, Manuel E. Osorio, and Kajetan Zwirglmaier (2019). Stay Strong - How to Fight a Price War, Simon Kucher \& Partners.

Zingales, Luigi (2017). Towards a Political Theory of the Firm, Journal of Economic Perspectives, 31(3), 113-130.

Zook, Chris, and Darrell Rigby (2008). How to Think Strategically in a Recession, Harvard Business Review. 